\title{
The Prophylactic Effect of Probiotic Enterococcus lactis IW5 against Different Human Cancer Cells
}

\author{
Yousef Nami', Babak Haghshenas ${ }^{1}$, Minoo Haghshenas ${ }^{2}$, Norhafizah Abdullah ${ }^{3}$ and \\ Ahmad Yari Khosroushahi ${ }^{4,5 *}$ \\ ${ }^{1}$ Institute of Biosciences, Universiti Putra Malaysia, Selangor, Malaysia, ${ }^{2}$ School of Medicine, Shahid Beheshti University of \\ Medical Sciences, Tehran, Iran, ${ }^{3}$ Chemical and Environmental Engineering Department, Faculty of Engineering, Universiti \\ Putra Malaysia, Selangor, Malaysia, ${ }^{4}$ Drug Applied Research Center, Tabriz University of Medical Sciences, Tabriz, Iran, \\ ${ }^{5}$ Department of Pharmacognosy, Faculty of Pharmacy, Tabriz University of Medical Sciences, Tabriz, Iran
}

\section{OPEN ACCESS}

Edited by:

Diana Bahia,

Universidade Federal de Minas

Gerais, Brazil

Reviewed by:

Amit Kumar Tyagi,

The University of Texas MD Anderson

Cancer Center, USA

Sahdeo Prasad,

The University of Texas MD Anderson

Cancer Center, USA

*Correspondence:

Ahmad Yari Khosroushahi

Yarikhosroushahia@tbzmed.ac.ir

Specialty section:

This article was submitted to

Microbial Immunology,

a section of the journal

Frontiers in Microbiology

Received: 18 June 2015 Accepted: 09 November 2015 Published: 26 November 2015

Citation:

Nami Y, Haghshenas $B$,

Haghshenas $M$, Abdullah $N$ and Yari

Khosroushahi A (2015)

The Prophylactic Effect of Probiotic

Enterococcus lactis IW5 against

Different Human Cancer Cells.

Front. Microbiol. 6:1317.

doi: 10.3389/fmicb.2015.01317
Enterococcus lactis IW5 was obtained from human gut and the potential probiotic characteristics of this organism were then evaluated. Results showed that this strain was highly resistant to low $\mathrm{pH}$ and high bile salt and adhered strongly to Caco2 human epithelial colorectal cell lines. The supernatant of E. lactis IW5 strongly inhibited the growth of several pathogenic bacteria and decreased the viability of different cancer cells, such as HeLa, MCF-7, AGS, HT-29, and Caco-2. Conversely, $E$. lactis IW5 did not inhibit the viability of normal FHs-74 cells. This strain did not generate toxic enzymes, including $\beta$-glucosidase, $\beta$-glucuronidase, and $N$-acetyl$\beta$-glucosaminidase and was highly susceptible to ampicillin, gentamycin, penicillin, vancomycin, clindamycin, sulfamethoxazol, and chloramphenicol but resistant to erythromycin and tetracyclin. This study provided evidence for the effect of E. lactis IW5 on cancer cells. Therefore, E. lactis IW5, as a bioactive therapeutics, should be subjected to other relevant tests to verify the therapeutic suitability of this strain for clinical applications.

Keywords: anticancer, enzyme activity, antibiotic susceptibility, apoptosis, cytotoxicity

\section{INTRODUCTION}

Probiotics are non-pathogenic live microorganisms that provide health benefits when these organisms are consumed in sufficient amounts (FAO/WHO, 2001; Mehra et al., 2012; Howarth and Wang, 2013; Haghshenas et al., 2014a; Nami et al., 2014a). Probiotics have been utilized to prevent bacterial infections (Forsyth et al., 2009) and treat cancer (Baldwin et al., 2010; Haghshenas et al., 2014b, 2015a,b; Nami et al., 2014b,c,d). These organisms can also create an acidic environment in the colon by producing short-chain fatty acids. Furthermore, probiotic bacteria can inhibit the occurrence of cancer by (i) lowering $\mathrm{pH}$, (ii) reducing the level of pro-carcinogenic enzymes (Donaldson, 2004), (iii) enhancing cell proliferation by inhibiting normal cell apoptosis and by promoting cell differentiation and cytoprotective activities (Lin et al., 2008), and (iv) suppressing inflammation-induced cell apoptosis (Prisciandaro et al., 2011) caused by lactic acid bacteria (LAB), including Lactobacillus, Enterococcus, Streptococcus, and Bifidobacterium. Among these LABs, the genus Enterococcus has gained considerable interest in environmental, food, and clinical research (Sharma et al., 2012).

Enterococcus is ubiquitous in nature and considered as the most controversial LAB genus because of unclear functions (Galvez et al., 2009). Enterococci have been utilized as adjutants 
to treat human and animal diseases. Enterococci have also been used in the food industry as probiotics (Franz et al., 2003) or as starter cultures because these microorganisms produce useful bacteriocins (Fisher and Phillips, 2009). Although Enterococcus comprises many species, only a few species are recognized as probiotics, such as E. faecalis, E. faecium, and E. lactis. Probiotics should exhibit important characteristics, such as tolerant to gastrointestinal conditions (acid and bile) and non-pathogenic; probiotics should also display competitive exclusion of pathogens (Collins et al., 1998; Ouwehand et al., 2002). Thus, the selection criteria of probiotic bacteria for clinical applications should be carefully evaluated. This study aimed to determine the probiotic properties (bile tolerance, antimicrobial activity, and antibiotic susceptibility) and antitumor activities of E. lactis isolated from the human gut.

\section{MATERIALS AND METHODS}

\section{Bacterial Strain and Culture Condition}

Enterococcus lactis IW5 was isolated from human fecal samples using streak plate method previously described by Shin et al. (2015) and this strain was maintained at $-70^{\circ} \mathrm{C}$ in de Man Rogosa broth (MRS, Merck, Germany) containing 25\% (v/v) glycerol. E. lactis IITRHR1 isolated from cheese was used as a control strain. Working cultures were anaerobically incubated at $37^{\circ} \mathrm{C}$ for $24 \mathrm{~h}$ in an anaerobic jar (Mitsubishi Inc. USA) that contains anaerobic gas generation kits (AnaeroPack).

\section{Tolerance to Artificial Gastric Juice and Artificial Bile Acid}

Tolerance to artificial gastric juice and bile acid were determined according to previously described method with slight modification (Lee et al., 2014). E. lactis was suspended in MRS containing $0.1 \%$ pepsin (Sigma, St. Louis, MO, USA) and adjusted to a $\mathrm{pH}$ of 2.0 with $0.1 \mathrm{M} \mathrm{HCl}$, and then incubated for $3 \mathrm{~h}$ at $37^{\circ} \mathrm{C}$. Artificial bile acid tolerance was measured by cultivating cells treated with artificial gastric juice. The cells were incubated at $37^{\circ} \mathrm{C}$ for $24 \mathrm{~h}$ in artificial bile acid consisting of MRS containing $0.3 \%$ oxgall (Becton Dickinson, Sparks, MD, USA). The numbers of viable cells were measured by incubating aliquots for $24 \mathrm{~h}$ on MRS agar plates at $37^{\circ} \mathrm{C}$. The survival rate was calculated using the formulation:

Survival rate $(\%)=(\log \mathrm{CFU}$ after reaction/Log $\mathrm{CFU}$ at $0 \mathrm{~h}) \times 100$

\section{Antimicrobial Susceptibility Assay}

Thirteen pathogenic organisms from the Persian Type Culture Collection (Table 1) were selected to detect antagonistic substances. Well diffusion was performed to detect inhibitory substances produced in the supernatant fluid of the isolate. For this purpose, an overnight culture of the indicator strains was used to inoculate appropriate agar growth media (Dimitonova et al., 2007) at $37^{\circ} \mathrm{C}$. Wells with a diameter of $5 \mathrm{~mm}$ were cut into agar plates; afterward, $50 \mu \mathrm{L}$ of filtered cell-free supernatant obtained from the third subculture of the microorganisms grown in MRS broth (cell density $10^{8} \mathrm{cfu} / \mathrm{mL}$ ) was added to each well. The supernatant was obtained by growing inhibitory producer strains overnight in MRS broth at $37^{\circ} \mathrm{C}$. The cells were removed through centrifugation; the supernatant was placed in the wells and allowed to diffuse in agar for $2 \mathrm{~h}$ at room temperature. The plates were incubated at optimum growth temperature of the indicator strains and examined after $24 \mathrm{~h}$ to determine inhibition zone areola diameter (Nowroozi et al., 2004; Maldonado et al., 2012).

\section{Enzyme Activity}

Enzyme activity was evaluated using an API ZYM kit (BioMerieux, Paris, France). E. lactis IW5 was suspended in sterile saline $(0.85 \% \mathrm{NaCl})$ at $10^{5} \mathrm{CFU} / \mathrm{mL}$ and added to each cupule. After inoculation was performed, the cultures were incubated at $37^{\circ} \mathrm{C}$ for $4 \mathrm{~h}$. One drop of ZYM B reagent was added and a drop of surface-active agent (ZYM reagent) was added to each cupule. ZYM A was introduced to facilitate ZYM $B$ solubilization in the medium. The resulting color was observed for at least $5 \mathrm{~min}$. Values ranging from 0 to 5 were assigned on the basis of color strength to determine the approximate amount (in nmol) of hydrolyzed substrate.

\section{Cell Cultures}

Five human cancer lines, namely, Caco-2 (human colorectal carcinoma cell), AGS (human gastric carcinoma cell), MCF-7 (human breast carcinoma cell), HeLa (human cervical carcinoma cell), and HT-29 (human colon carcinoma cell), and one normal cell line, namely, FHs-74 (human intestinal epithelial cells) - obtained from cell resource center of Pasteur institute of Iran (Tehran, Iran) - were used to investigate the anticancer effects of E. lactis IW5. The cells were grown in RPMI1640 medium supplemented with $10 \%$ heat-inactivated fetal bovine serum and a $1 \%$ penicillin-streptomycin mixture. The cultures were maintained at $37{ }^{\circ} \mathrm{C}$ in an atmosphere of $95 \%$ $\mathrm{O}_{2}$ and $5 \% \mathrm{CO}_{2}$ with relative humidity (Merghoub et al., 2009).

\section{Cell-free Culture Supernatant Preparation}

The liquid culture of E. lactis at the end of the exponential growth phase was centrifuged at $4000 \times g$ for $10 \mathrm{~min}$ to obtain cell precipitates. The supernatant was collected; $\mathrm{pH}$ was adjusted to 7.2 with $1 \mathrm{~N} \mathrm{NaOH}$ and subjected to lyophilization. Endogenous proteases were inactivated by heat at $100 \mathrm{C}$ for $3-5 \mathrm{~min}$. The desired concentrations of lyophilized culture supernatant (10$50 \mu \mathrm{g} / \mathrm{mL}$ ) were prepared in RPMI media by diluting from stock solution (10 mg lyophilized supernatant/mL RPMI media) and sterilized by filtering the supernatant through a $0.22 \mu \mathrm{m}$ bacterial filter (Millipore); the prepared supernatant was then used to treat cancer cells.

\section{Adhesion to Caco-2 Cells}

Enterococcus lactis IW5 was assessed for its adhesion ability to the human colon carcinoma cell line, Caco-2. The cells were seeded in RPMI-1640 medium supplemented with 10\% heat-inactivated 
TABLE 1 | The inhibitory effect of Enterococcus lactis IW5 against pathogenic bacteria.

\begin{tabular}{|c|c|c|c|}
\hline Test organisms & Growth conditions & Origin & Susceptibility \\
\hline Salmonella typhimurium & MPA, $37^{\circ} \mathrm{C}$ & ATCC 14028 & $\mathrm{R}$ \\
\hline Escherichia coli O26 & $\mathrm{LB}, 37^{\circ} \mathrm{C}$ & Native strain & S \\
\hline E. coli 0157 & $\mathrm{LB}, 37^{\circ} \mathrm{C}$ & PTCC 1276 & $\mathrm{R}$ \\
\hline Staphylococcus aureus & Blood agar, $37^{\circ} \mathrm{C}$ & ATCC 25923 & $S$ \\
\hline Bacillus cereus & $\mathrm{MPA}, 37^{\circ} \mathrm{C}$ & PTCC 1539 (ATCC 11778) & S \\
\hline Listeria monocytogenes & $\mathrm{BHI}, 37^{\circ} \mathrm{C}$ & PTCC 1163 & ES \\
\hline Klebsiella pneumoniae & MPA, $37^{\circ} \mathrm{C}$ & PTCC 1053 (ATCC 10031) & $S$ \\
\hline Shigella flexneri & $\mathrm{MHA}, 37^{\circ} \mathrm{C}$ & PTCC 1234 (NCTC 8516) & $S$ \\
\hline Pseudomonas aeroginosa & MPA, $37^{\circ} \mathrm{C}$ & PTCC 1181 & $\mathrm{R}$ \\
\hline Candida albicans & $\mathrm{MHA}, 28^{\circ} \mathrm{C}$ & PTCC 5027 (ATCC 10231) & $\mathrm{R}$ \\
\hline Serratia marcesens & $\mathrm{MHA}, 37^{\circ} \mathrm{C}$ & PTCC 1187 (Native strain) & $\mathrm{R}$ \\
\hline Streptococcus mutans & $\mathrm{MHA}, 37^{\circ} \mathrm{C}$ & PTCC 1683 (ATCC 35668) & SS \\
\hline Staphylococcus & Blood agar, $37^{\circ} \mathrm{C}$ & PTCC 1440 (CIP 76.125) & $R$ \\
\hline
\end{tabular}

R: 0 mm; SR: 0-4 mm; SS: 4-8 mm; S: 8-12 mm; ES: > $12 \mathrm{~mm}$.

CIP, Collection of Bacteries de I'Institute Pasteur, Paris, France; ATCC, American Type Culture Collection, Virginia, USA; NCTC, National Collection of Type Cultures, London, UK; PTCC, Persian Type Culture Collection, Tehran, Iran.

MPA, mycophonolic acid; LB, Lysogeny broth; BHI, Brain-heart infusion medium; MHA, Mueller Hinton Agar.

fetal bovine serum and $1 \%$ penicillin/streptomycin mixture. Cells were seeded on 24-well tissue culture plates and incubated at $37^{\circ} \mathrm{C}$ in $5 \% \mathrm{CO}_{2}$ in a relatively humid atmosphere until a confluent monolayer was achieved. Adherence assay was carried out by adding $1 \mathrm{~mL}$ of the bacterial strain, suspended in RPMI1640 medium, at a concentration of about $1 \times 10^{7} \mathrm{CFU} /$ well and was incubated for $3 \mathrm{~h}$ at $37^{\circ} \mathrm{C}$ in an atmosphere of $5 \%(\mathrm{v} / \mathrm{v})$ $\mathrm{CO}_{2}$. Before the adhesion assay, the media in the wells containing a Caco- 2 cell monolayer were removed and replaced once with fresh antibiotic-free RPMI.

To remove non-attached bacterial cells, the wells were washed three times with a sterile, pre-warmed PBS solution. To detach the cells from the wells, $1 \mathrm{~mL}$ of trypsin/EDTA solution $(0.5 \%$ porcine trypsin and $0.2 \%$ EDTA in PBS; Sigma) was added to each well and the mixture was gently stirred for $5 \mathrm{~min}$. To measure the viable Caco- 2 cell count, the cells were counted by the pure plate method onto MRS agar medium and incubated at $37^{\circ} \mathrm{C}$ under anaerobic conditions. Bacterial adhesion was expressed as the total number of bacteria attached to viable Caco- 2 cells.

\section{Cytotoxicity against Different Cancer Cells}

The cytotoxicity of the isolated E. lactis on tumor/normal cells was evaluated through a microculture tetrazolium [MTT, 3-(4, 5-dimethylthiazol-2-yl)-2,5-diphenyltetrazolium bromide] assay (Mosmann, 1983). In brief, HeLa, AGS, MCF-7, HT-29, Caco2 , and FHs 74 cells $\left(1.2 \times 10^{4}\right.$ cells/well $)$ were seeded in each well of a 96-well microplate with RPMI growth medium. Once $50 \%$ confluence was reached $24 \mathrm{~h}$ after the cells were seeded, the cells were treated with the filtered supernatant of the isolated strain at different time points $(12,24$, and $48 \mathrm{~h})$. After treatment was administered, the medium was replaced with $200 \mu \mathrm{l}$ of fresh medium containing $50 \mu \mathrm{l}$ of MTT solution $(2 \mathrm{mg} / \mathrm{mL}$ in PBS) and incubated for another $4 \mathrm{~h}$ at $37 \mathrm{C}$. After incubation was completed, the MTT mixture was carefully removed, and $200 \mu \mathrm{l}$ of dimethyl sulfoxide and $25 \mu \mathrm{l}$ of Sorenson's glycine buffer $(0.1 \mathrm{M}$ glycine and $0.1 \mathrm{M} \mathrm{NaCl}$ at $\mathrm{pH} 10.5)$ were added to each well and incubated for $30 \mathrm{~min}$. The absorbance of each well was determined after $30 \mathrm{~s}$ of shaking by using a microplate reader (Biotek, ELx 800, USA) at $570 \mathrm{~nm}$. The cells treated with MRS (bacterial culture medium) and Taxol (anticancer drug as a reference) served as negative and positive controls, respectively.

\section{Apoptotic Cells Detection 4',6-diamidino-2-phenylindole (DAPI) staining}

All of the cultured cells (treated/untreated groups) were evaluated through 4',6-diamidino-2-phenylindole (DAPI) staining to detect apoptotic cells. For this purpose, sterile cover slips were placed in each of the six wells of the culture plate. Cancer cells $\left(120 \times 10^{4}\right.$ cells/well $)$ were added to each well and maintained under the desired standard culture condition. At $24 \mathrm{~h}$ after the cells were seeded, all of the cultured cells were subjected to E. lactis secretion, MRS medium, and Taxol ( $\mathrm{IC}_{50}$ concentration) treatments. The treated and untreated control groups were incubated for another $24 \mathrm{~h}$ and prepared for apoptosis assay. Afterward, 4\% paraformaldehyde was added to each well to stain cells with DAPI dye. The cells were fixed and permeabilized with $0.1 \%$ Triton-X100 for $5 \mathrm{~min}$. The permeabilized cells were stained with $50 \mu \mathrm{l}$ of DAPI dye (1:2000 dilutions) and incubated for $3 \mathrm{~min}$ at room temperature. The processed cells with cover slips were washed thrice with PBS ( $\mathrm{pH}$ 7.2) and utilized to assess apoptosis by using a fluorescent microscope (BX64, Olympus, Japan) equipped with a U-MWU2 fluorescence filter (excitation filter BP 330-385, dichromatic mirror DM 400, and emission filter LP 420; Paolillo et al., 2009).

\section{Flow cytometry}

The fraction of apoptotic cells was quantitatively measured via flow cytometry using the Annexin V-FITC apoptosis detection kit (eBioscience, San Diego, CA, USA). HeLa cell line $\left(1.2 \times 10^{5}\right.$ cells/well $)$ was seeded into a six-well culture plate and the treatment of cells were similar to DAPI staining. After treatment time point $(24 \mathrm{~h})$, the treated/untreated control cells 
were detached by trypsin, the supernatant was discarded after centrifugation at $900 \mathrm{rpm}$ for $10 \mathrm{~min}$ at $28 \mathrm{C}$, and the cell pellet was resuspended in $500 \mu \mathrm{l}$ of $1 \times$ binding buffer and transferred into a new $5 \mathrm{ml}$ tube. The tubes were centrifuged again and the supernatants were replaced with $100 \mu \mathrm{l}$ binding buffer $(1 \times)$. Afterward, the tubes were added with $5 \mu$ l of FITCconjugated Annexin $\mathrm{V}$ then were incubated for $15 \mathrm{~min}$ at room temperature under dark conditions. The incubated cells were centrifuged and the cell plates were resuspended in $500 \mu \mathrm{l}$ of binding buffer $(1 \times)$. Finally, $5 \mu$ l of propidium iodide solution was added to the cells, and quadrant settings were fixed with untreated, single-stained controls, and copied to dot plots of the treated cells. Quadrant statistic calculations were performed using CELLQuest Pro software (BD Biosciences, San Jose, CA, USA). The experiment was repeated two times with triplicate samples for each experiment. Analyses were accomplished using 10000 cells at a rate of 450 cells/s.

\section{Quantitative Real Time PCR}

For RNA analysis, HeLa cells were lysed using TRI Reagent ${ }^{\circledR}$ (Sigma Chemical Co., Poole, UK) according to manufacture guidelines. $24 \mathrm{~h}$ post-treatment or untreated control monolayer cells were lysed by adding desired amount of TRI Reagent ${ }^{\circledR}(2 \mathrm{~mL}$ per $25 \mathrm{~cm} 2$ T-flask) accordingly were homogenized and transferred to RNAse/DNAse-free microtubes. Chloroform $\left(0.2 \mathrm{~mL}\right.$ per each $\mathrm{mL}$ of TRI Reagent ${ }^{\mathrm{TM}}$ used for lysing) was added to each sample, and the mixture was vortexed. After maintaining at room temperature for $5 \mathrm{~min}$, the samples were centrifuged at $12000 \times g, 4^{\circ} \mathrm{C}$ and $10 \mathrm{~min}$ and the colorless supper aqueous phase was carefully separated and mixed with ice-cold isopropanol $\left(0.5 \mathrm{~mL}\right.$ per each $\mathrm{mL}$ of TRI Reagent ${ }^{\circledR}$ used initially). The mixture was centrifuged at $12000 \times \mathrm{g}, 4^{\circ} \mathrm{C}$ for $10 \mathrm{~min}$, yielding total RNA pellet that was washed with $75 \%$ ethanol $(\times 3)$. The air dried samples were dissolved in DEPC treated water and tested qualitatively and quantitatively prior to its use for RT-PCR experiments.

The isolated RNA was reverse transcribed to cDNA using Moloney- murine leukemia virus (MMLV) reverse transcriptase (Bethesda Research Laboratories, Gaithersburg, MD, USA). For RT reaction, $1 \mu \mathrm{L}$ RNA $(1 \mu \mathrm{g} / \mu \mathrm{L})$ was mixed with master mix [DEPC treated water $13 \mu \mathrm{L}$, dNTP's $(10 \mu \mathrm{M}) 2 \mu \mathrm{L}$, MMLV buffer with DTT $2 \mu \mathrm{L}$, random hexamer primer (pdN6; $400 \mathrm{ng} / \mu \mathrm{L}$ ) $0.5 \mu \mathrm{L}]$, and denatured at $95^{\circ} \mathrm{C}$ for $5 \mathrm{~min}$. The sample was then cooled down to $4^{\circ} \mathrm{C}$ for $5 \mathrm{~min}$ using ice-bath. Then $1 \mu \mathrm{L}$ MMLV $(200 \mathrm{U} / \mu \mathrm{L})$ and $0.5 \mu \mathrm{L}$ RNase in $(40 \mathrm{U} / \mu \mathrm{L})$ were added to the sample and the mixture was incubated using following thermocycling program: $10 \mathrm{~min}$ at $25^{\circ} \mathrm{C}, 42 \mathrm{~min}$ at $42^{\circ} \mathrm{C}$, and 5 min at $95^{\circ} \mathrm{C}$. The prepared cDNA templates were used for real time PCR experiments.

Primers were designed from published Gene Bank sequences using Beacon Designer 5.01 (Premier Biosoft International, http://www.premierbiosoft.com) and listed in Table 3. All amplification reactions were performed in a total volume of $25 \mu \mathrm{L}$ using iQ5 Optical System (Bio-Rad Laboratories Inc., Hercules, CA, USA). Each well contained: $1 \mu \mathrm{L}$ cDNA, $1 \mu \mathrm{L}$ primer (100 nM each primer), $12.5 \mu \mathrm{L} 2 \times$ Power SYBR Green PCR Master Mix (Applied Biosystems, Foster City, CA, USA), and
$10.5 \mu \mathrm{L}$ RNAse/DNAse free water. Thermal cycling conditions were as follow: $1 \mathrm{cycle}$ at $94^{\circ} \mathrm{C}$ for $10 \mathrm{~min}, 40$ cycles at $95^{\circ} \mathrm{C}$ for $15 \mathrm{~s}, 56-62^{\circ} \mathrm{C}$ (annealing temperature) for $30 \mathrm{~s}$, and $72^{\circ} \mathrm{C}$ for $25 \mathrm{~s}$. Interpretation of the result was performed using the Pfaffle method and the threshold cycle $\left(C_{t}\right)$ values were normalized to the expression rate of GAPDH as a housekeeping gene. All reactions were performed in triplicate and negative controls were included in each experiment.

\section{Statistical Analysis}

Data were analyzed by one-way ANOVA. Significant differences of means $(p<0.05)$ were compared through Duncan's test by using SPSS 19.0. Graphs were prepared using Microsoft Office Excel (Rahmati, 2011).

\section{RESULTS AND DISCUSSION}

\section{Isolation and Identification}

The bacterial strain was isolated from the human gut. The strain was initially identified by phenotypic methods; the Gram reaction of the isolates was determined by observation under a light microscope after Gram staining by using a Gram staining kit. LAB were considered Gram positive when they appeared bluepurple upon Gram staining. The isolates did not produce gas bubbles when hydrogen peroxide solution (3\%) drops (SigmaAldrich, USA) were added to bacterial cells to determine catalase positive/negative strains; hence, the result confirmed that this strain is a Gram-positive and catalase-negative bacterium. A total of $45 \mathrm{Gram}$-positive and catalase-negative strains were obtained. Based on 16S rRNA identification results, the 45 isolated bacteria were classified into three major groups of LAB: enterococci, lactobacilli, and lactococci. After sequencing was performed, the strains belonging to Enterococcus genus were categorized into nine different species: one E. lactis, two E. pseudoavium, four E. hirae, two E. gilvus, four E. avium, three E. durans, eight E. faecalis, five E. malodoratus, and seven E. faecium. Moreover, lactobacilli were classified into three diverse species: one L. casei, three L. acidophilus, and one L. plantarum. Lactococci were classified into one species: three Lactococcus lactis, with two subspecies, namely, L. lactis ssp. lactis and L. lactis ssp. cremoris.

Probiotics have been extensively investigated because these organisms provide health benefits when such probiotics are consumed in sufficient amounts. In this study, LAB species with probiotic and antitumor activities were isolated; the strains that could grow in $5 \% \mathrm{CO}_{2}$ atmosphere. An E. lactis strain (Accession number: HF562969.1) resistant to $\mathrm{pH} 2.0$ and $0.3 \%$ bile salt was isolated from the human gut and then identified.

\section{Acid and Bile Tolerance}

The survival of E. lactis IW5 and E. lactis IITRHR1 in artificial gastric juice $(\mathrm{pH} 2.0,0.1 \%$ pepsin, for $3 \mathrm{~h}$ ) and artificial bile salt $(0.3 \%$ oxgall, for $24 \mathrm{~h})$ was evaluated (Table 1$)$. The cells of E. lactis IW5 and E. lactis IITRHR1 were strongly maintained, with 94.60 and $92.27 \%$ survival rate in artificial gastric juice, respectively. In artificial bile salt, the cells of E. lactis IW5 and E. lactis IITRHR1demonstrated 95.46 and $94.14 \%$ survival rate, 
respectively. Our findings are similar to those of previous studies, which revealed that the survival rates of Enterococcus bacteria treated with acid and bile range from 63 to 100\% (Haghshenas et al., 2014b; Nami et al., 2014d). Similarly, it has been revealed that Enterococcus bacteria were very stable in acidic conditions ( $\mathrm{pH} 2$ for $3 \mathrm{~h}$ ) and high bile salt $(0.3 \%$ oxgall for $4 \mathrm{~h}$; Bhardwaj et al., 2010).

\section{Antimicrobial Susceptibility Assay}

The antimicrobial susceptibility spectrum of E. lactis IW5 is shown in Table 2. This strain inhibited the growth of pathogenic bacteria, including Escherichia coli O26, Staphylococcus aureus, Bacillus cereus, Klebsiella pneumoniae, Shigella flexneri, and Streptococcus mutans. Moreover, E. lactis exhibited strong activity against Listeria monocytogenes. No significant activity was observed against Serratia marcesens, Pseudomonas aeruginosa, Candida albicans, Staphylococcus saprophyticus, Escherichia coli O157, and Salmonella typhimurium.

The $50 \%$ inhibitory concentration $\left(\mathrm{IC}_{50}\right)$ of isolated strain metabolites was determined as an index of antagonistic activity from the antimicrobial time and dose-dependent curves. After $24 \mathrm{~h}$ of incubation, $\mathrm{IC}_{50}$ values were only observed in E. coli $\mathrm{O} 26$, S. aureus, B. cereus, K. pneumoniae, S. flexneri, S. mutans, and L. monocytogenes cells treated with E. lactis secretions. The $\mathrm{IC}_{50}$ for E. lactis secretions on E. coli O26, S. aureus, and B. cereus cells was 47, 28 and $32 \mu \mathrm{g} / \mathrm{mL}$, respectively. The $\mathrm{IC}_{50}$ values of E. lactis secretions on K. pneumoniae, S. flexneri, and S. mutans cells was 31, 26 and $22 \mu \mathrm{g} / \mathrm{mL}$, respectively. The $\mathrm{IC}_{50}$ value of E. lactis secretions on L. monocytogenes cells showed the lowest value $(13 \mu \mathrm{g} / \mathrm{mL})$. Our results showed that the E. lactis IW5 strain obtained from the human gut exhibited good probiotic properties, such as low $\mathrm{pH}$ and bile salt resistance. This strain was capable to inhibit several pathogenic bacteria.

\section{Enzyme Activity}

Certain enzymes are characteristically produced by probiotics to provide protection from toxic substances. $\beta$-glucosidase, $N$-acetyl- $\beta$-glucosaminidas, and $\beta$-glucuronidase have been associated with certain health disorders (Chen et al., 2014). $\beta$-glucuronidase increases the risk of carcinogenesis by secreting toxins and mutagens (Delgado et al., 2007; Dabek et al., 2008). These toxic enzymes could be produced by microorganisms.

TABLE 2 | Tolerance of E. lactis IW5 and E. lactis IITRHR1 against artificial gastric and bile conditions.

\begin{tabular}{ll}
\hline Treatment & Log CFU/mL \\
\hline E. lactis IW5 & \\
Initial cell no. & $8.15 \pm 0.26$ \\
pH 2.0, 0.1\% pepsin, 2 h & $7.71 \pm 0.12$ \\
0.3\% oxgall, 24 h & $7.78 \pm 0.36$ \\
E. lactis IITRHR1 & \\
Initial cell no. & $8.36 \pm 0.18$ \\
pH 2.0, 0.1\% pepsin, 2 h & $7.71 \pm 0.21$ \\
$0.3 \%$ oxgall, 24 h & $7.87 \pm 0.19$ \\
\hline
\end{tabular}

The results are represented as mean $\pm S D$.
Our data demonstrated that E. lactis did not produce toxic enzymes, including $\beta$-glucosidase, $N$-acetyl- $\beta$-glucosaminidase, and $\beta$-glucuronidase. Conversely, $E$. lactis produced various enzymes, including esterase $(20 \mathrm{nmol})$, acid and alkaline phosphatase ( $5 \mathrm{nmol})$, and esterase lipase ( $\geq 25 \mathrm{nmol})$.

\section{Adhesion Ability to Colon Endothelial Cells}

Several investigations have implicated a number of factors in the attachment of probiotic bacterial cells to epithelial cells. Such factors include: passive entrapment of the bacterial cells by fimbrial cell matrix material (Sarem et al., 1996), bacterial cell surface-associated lipoteichoic acid (Granato et al., 1999), proteinaceous extracellular adhesins (Conway and Kjelleberg, 1989), and bacterial cell surface-associated proteinaceous factors (Adlerberth et al., 1996). Adhesion of E. lactis IW5 and E. lactis IITRHR1 was confirmed by using the plating technique. When E. lactis IW5 was plated at a concentration of $8.35 \pm 0.06 \log$ $\mathrm{CFU} /$ well, we found that $8.16 \pm 0.04 \log \mathrm{CFU} /$ well of the bacteria adhered to the Caco-2 cells. Conversely, when E. lactis IITRHR1 was plated at a concentration of $8.13 \pm 0.05 \log$ CFU/well, it was found that only $6.45 \pm 0.03 \log \mathrm{CFU} /$ well of the bacteria adhered to the Caco- 2 cells. It has been reported previously that E. lactis IITRHR1 can strongly adhere to intestinal epithelial cells, which promote its survival and show a broad range of antimicrobial activity (Sharma et al., 2011). Similar to our findings, these data demonstrated that the bacterial concentration was reduced by $1.68 \log \mathrm{CFU} /$ well, following removal of the non-adhered cells.

\section{Toxicity Assay}

Microculture tetrazolium assay was performed to determine the cytotoxicity effects of the metabolites secreted by E. lactis IW5 on various cancer cell lines, particularly HeLa, Caco-2, AGS, and HT-29. The cytotoxicity potential of the metabolites produced by E. lactis IW 5 on various cancer cells was determined (Figures 1 and $\mathbf{2 A - D , F ) . ~ A f t e r ~} 24 \mathrm{~h}$ of incubation, the metabolites inhibited all cancer cell lines. Approximately 38, 36, 28, 40, and $30 \%$ of MCF-7, HeLa, HT-29, AGS, and Caco-2 cells, respectively, remained viable after these cells were incubated with the metabolites for $24 \mathrm{~h}$. The antiproliferative effect of the metabolites on all of the evaluated cancer cells significantly differed from that of the un-treated and reference strain-treated groups. The effect of the metabolites on FHs 74 normal cells was also examined (Figure 2E). E. lactis IW5 secretions exhibited no toxic effect on normal cells; more than $95 \%$ of the cells grew well. These results indicated that E. lactis IW5 is a potential candidate for cancer treatment.

The anticancer activity of probiotic bacteria has been demonstrated by in vivo and in vitro systems (Ouwehand, 2007). Probiotic organisms inhibit mammalian cell proliferation in primary leukocyte cultures and cell lines. The induction of apoptotic cells by conjugated linoleic acid produced by various probiotic strains has been established in Caco-2 and HT-29 mammalian cancer cell lines. In this study, four human cancer cell lines, namely, Caco-2 (colorectal cancer), AGS (gastric cancer), HeLa (cervical cancer), and HT-29 (colon cancer), and 
TABLE 3 | Real time PCR genes and their forward/reverse primers.

\begin{tabular}{|c|c|c|c|c|}
\hline Primer & Forward and reverse primer & Sequence & Amplicon size & length \\
\hline & $\mathrm{R}$ & 5'-CCAGCCCATGATGGTTCTGAT-3' & 155 & 21 \\
\hline & $\mathrm{R}$ & 5'-CGGTTCAGGTACTCAGTCATCC-3' & 130 & 22 \\
\hline \multirow[t]{2}{*}{ CASPAS 9} & $\mathrm{~F}$ & 5'-CTCAGACCAGAGATTCGCAAAC-3' & 116 & 22 \\
\hline & $\mathrm{R}$ & 5'-GCATTTCCCCTCAAАCTCTCAA-3' & 116 & 22 \\
\hline & $\mathrm{R}$ & 5'-GCTCGGGCATACAGGCAAAT-3' & 116 & 20 \\
\hline \multirow[t]{2}{*}{ ErbB2 } & $\mathrm{F}$ & 5'-TGTGACTGCCTGTCCCTACAA-3' & 152 & 21 \\
\hline & $\mathrm{R}$ & 5'-CCAGACCATAGCACACTCGG-3' & 152 & 20 \\
\hline \multirow[t]{2}{*}{ ErbB3 } & $\mathrm{F}$ & 5'-GACCCAGGTCTACGATGGGAA-3' & 99 & 21 \\
\hline & $\mathrm{R}$ & 5'-GTGAGCTGAGTCAAGCGGAG-3' & 99 & 20 \\
\hline$B C L-X L$ & $\mathrm{~F}$ & 5'-GAGCTGGTGGTTGACTTCTC-3' & 101 & 21 \\
\hline
\end{tabular}

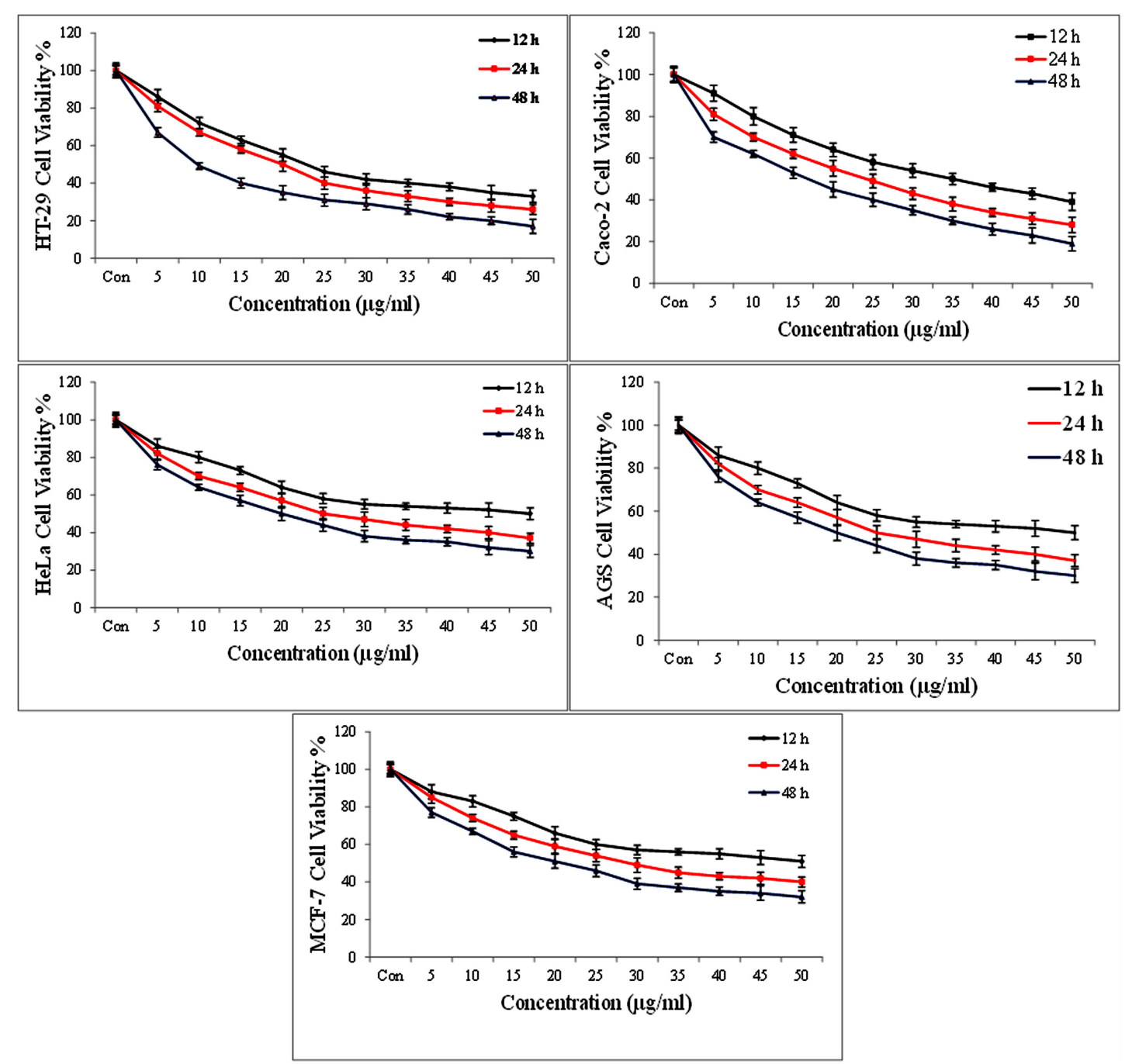

FIGURE 1 | The cytotoxic effects of isolated Entreococcus lactis IW5 secretion on different cancer cell lines at three time points 12, 24, and $48 \mathrm{~h}$. Error bars represent the standard deviation of the each mean. 


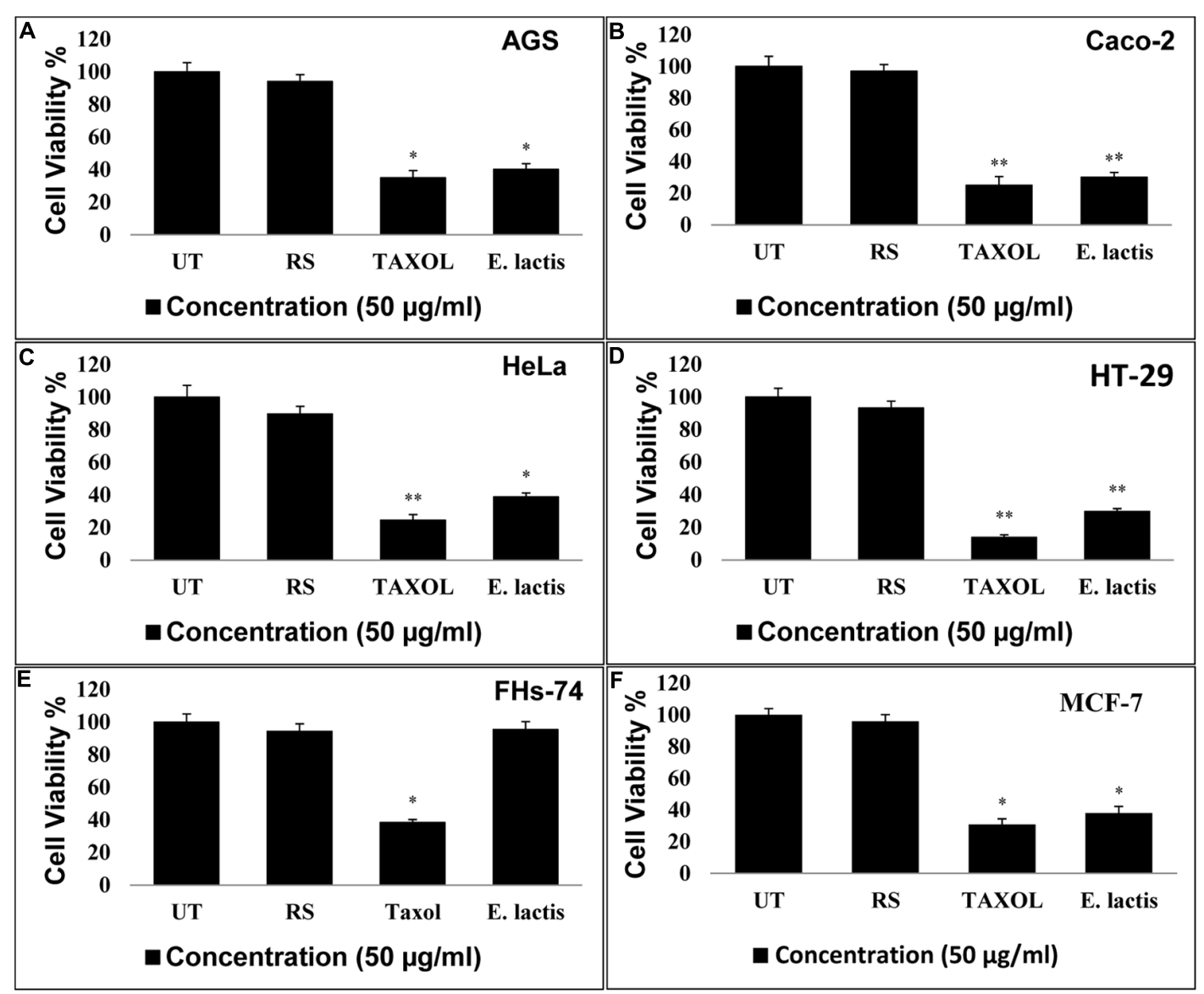

FIGURE 2 | Effect of E. lactis secretions on the proliferation of cancerous MCF-7, Caco-2, HT-29, HeLa, AGS, and FHs-74 normal cell lines. E. lactis secretions final concentration: $50 \mu \mathrm{g} / \mathrm{mL}$, Taxol concentration: $I_{50}$ for each cell line. Incubation time is $24 \mathrm{~h}$. Data are expressed as mean and error bars represent standard deviation of means. UT: Untreated media were used as control. E. lactis IITRHR1 was used as Reference Strain (RS) for comparison. Asterisks denote statistically significant differences $(* p<0.05 ; * *<0.01)$.

one normal cell line, namely, FHs-74, were utilized. The results of this study demonstrated that the metabolites secreted by E. lactis IW5 strain significantly inhibited the growth of the four cancer cell lines. E. lactis IW5 secretions decreased the proliferation and viability of all cancer cell lines but did not adversely affect FHs-74 normal cells. Therefore, this strain was considered non-toxic. Different cancer cells were treated with $10^{6} \mathrm{CFU} /$ well of E. lactis IW5; this treatment strongly inhibited the proliferation of cancer cells. In E. lactis IW5 treatment, the proliferation of MCF-7, HeLa, HT-29, AGS, and Caco-2 cells was particularly inhibited by $38,36,28,40$, and $30 \%$, respectively. Thus, E. lactis IW5 can inhibit the proliferation of cancer cells; however, E. lactis IITRHR1could not inhibit the proliferation of cancer cells.

\section{Apoptosis Assay}

HeLa cells were treated with $50 \mu \mathrm{g} / \mathrm{mL}$ of the filtered secretion after these cells were incubated for $24 \mathrm{~h}$; the treated HeLa cells were stained with DAPI and analyzed through fluorescent microscopy to analyze the effect of E. lactis secretions on HeLa cell viability. The intact viable cells displayed completely healthy nuclei (Figure 3a); by contrast, the apoptotic cells were characterized by shrunk cells with condensed (early apoptosis) or fragmented (late apoptosis) nuclei. Other morphological and apoptotic changes, such as membrane blebbing and apoptotic body formation, were observed in the treated cells. This result suggested that apoptosis is the main cytotoxic mechanism of bacterial metabolites (Figure 3b).The newly identified E. lactis IW5 strain obtained from the human gut exhibited appropriate probiotic properties, such as high tolerance to low $\mathrm{pH}$, resistance to high bile salt concentration, and antipathogenic activity against several pathogenic bacteria. Cytotoxic findings indicated that E. lactis IW5 secreted metabolites that possessed high anticancer activity against all of the examined cancer cell lines (AGS, Caco-2, HeLa, and HT-29). Therefore, the metabolites produced by E. lactis IW5 strain may be used as an alternative nutraceutical with promising therapeutic index because these metabolites are non-cytotoxic to normal mammalian cells.

Compared with the control cells that exhibited natural cell death (Figure 3c), the HeLa cells treated with $50 \mu \mathrm{L} / \mathrm{mL}$ of filtered $E$. lactis IW5 secretions demonstrated significant amounts 

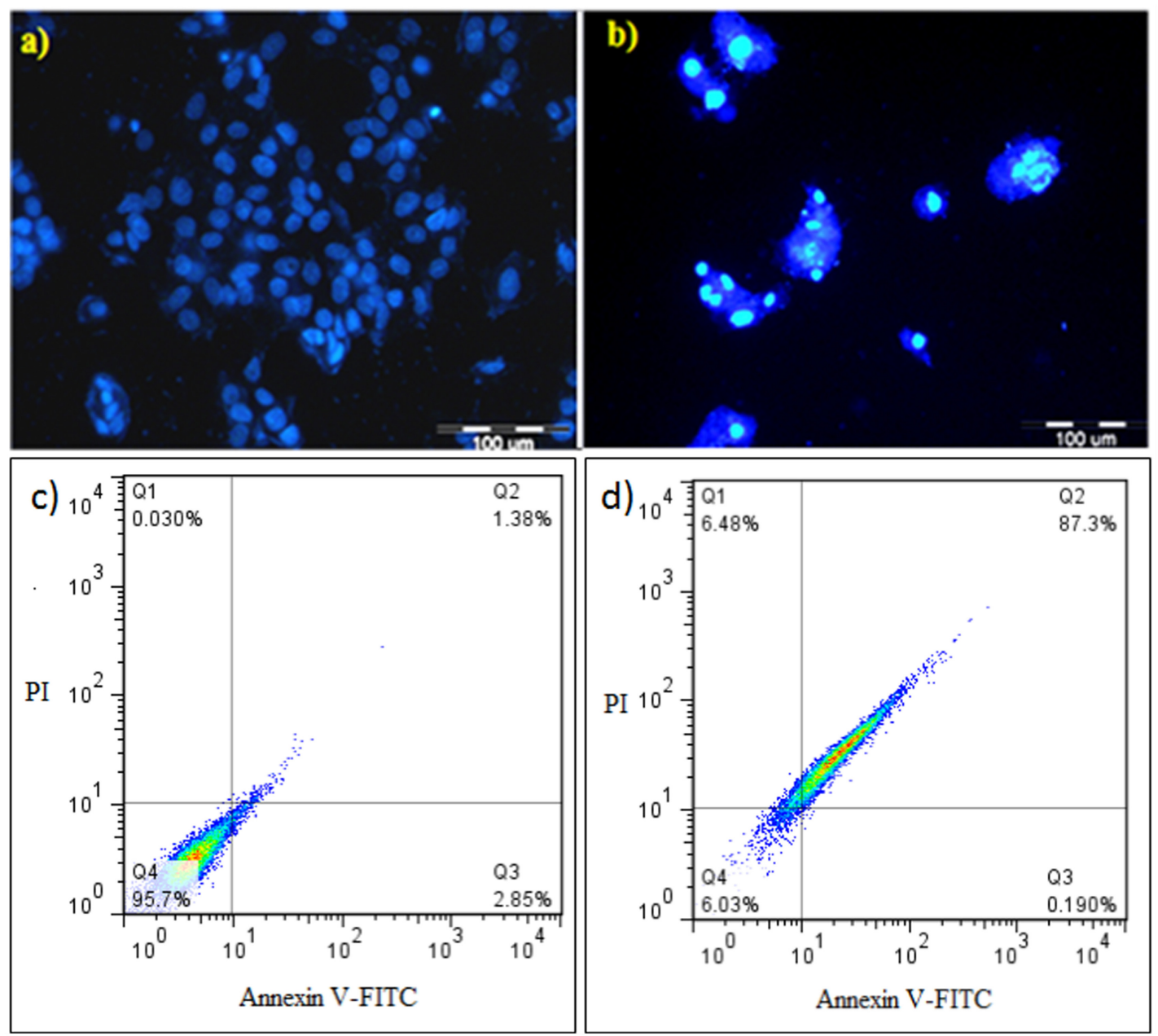

FIGURE 3 | 4',6-diamidino-2-phenylindole (DAPI) staining and flow cytometric analysis of treated/untreated HeLa cancer cells. (a,b) Untreated and treated DAPI-stained cells; (c,d) flow cytometric analysis of untreated and treated cells with $50 \mu \mathrm{g} / \mathrm{mL}$ E. lactis secretion metabolites after $24 \mathrm{~h}$ incubation. Dots with Annexin $\mathrm{V}^{-} / \mathrm{PI}^{+}(\mathrm{Q} 1)$, Annexin $\mathrm{V}^{+} / \mathrm{PI}^{+}(\mathrm{Q} 2)$, Annexin $\mathrm{V}^{+} / \mathrm{PI}^{-}(\mathrm{Q} 3)$, and Annexin $\mathrm{V}^{-} / \mathrm{PI}^{-}(\mathrm{Q} 4)$ and feature represent necrotic, late apoptotic, early apoptotic, and viable intact cells, respectively.

$(p \leq 0.05)$ of annexin $\mathrm{V}^{+} / \mathrm{PI}^{+}$(late apoptotic cells) after incubating for $24 \mathrm{~h}$ (Figure 3d). In the treated HeLa cells 87.3 and $6.48 \%$ were observed in late apoptosis and necrosis, respectively. Based on the flow cytometry findings, E. lactis IW5 secretions can inhibit the proliferation of cancer cells and the main mechanism of this prophylactic effect was related to apoptosis induction in cancer cells.

\section{Quantitative Real Time PCR}

As shown in Figure 4, the expression of anti-apoptotic genes (ERBB 2 and ERBB3), intrinsic apoptosis blocker genes (BCL-2 and BCL-XL), and CASP 8 gene (starter gene in TNF- $\alpha$ apoptosis pathway) were significantly down-regulated by $E$. lactis IW5compared to untreated control group. The down-regulation in the mentioned genes by E. lactis IW5 was similar to Taxol $^{\circledR}$ but the expression of CASP 9 (starter gene in intrinsic apoptosis pathway) and BAX (crucial gene in extrinsic IL-3 mediated apoptosis pathway) genes was significantly different in E. lactis IW5 and Taxol treated groups (Figure 4). E. lactis IW5 up-regulated the expression of BAX gene whereas Taxol up-regulated the expression of CASP9 indicating different inducing pathways of apoptosis. Lactobacillus paracasei M5L can induce apoptosis in HT29 cells through reactive oxygen species generation followed by CRT accompanied endoplasmic reticulum stress and S phase arrest (Hu et al., 2015). The molecular mechanisms of pro-apoptotic effects of human-derived Lactobacillus reuteri ATCC PTA 6475 has been previously investigated on myeloid leukemia-derived cells and findings have shown the downregulation of nuclear factor-kappaB (NF-kappaB)-dependent gene products that mediate cell survival (Bcl-2 and Bcl$\mathrm{xL}$ ) related genes (Iyer et al., 2008). Findings of antitumor effects of cell-bound exopolysaccharides (cb-EPS) isolated from Lactobacillus acidophilus 606 on HT-29 colon cancer cells have shown the antitumourigenic effects through the induction of BAX gene (Kim et al., 2010). In addition, the human 


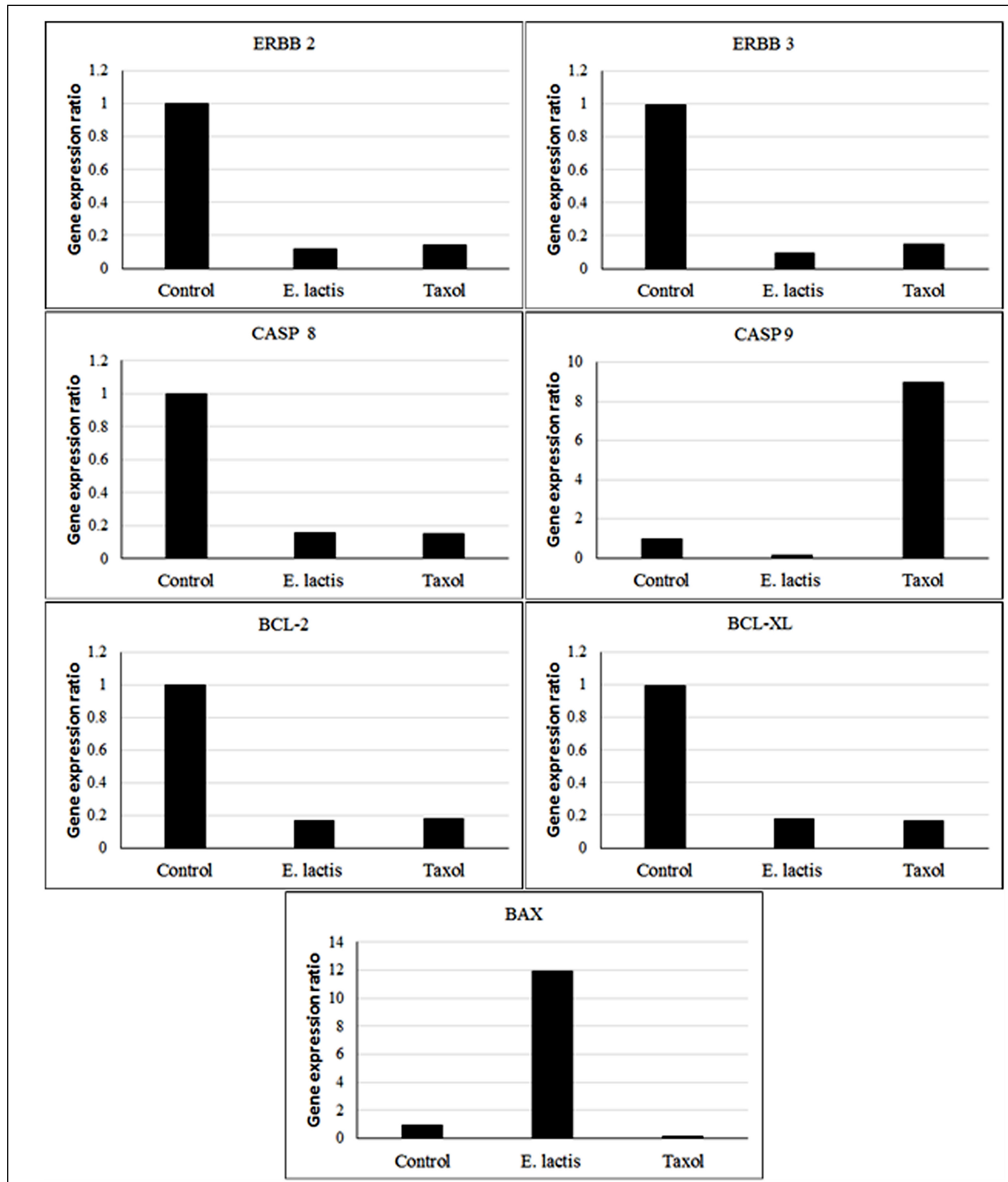

FIGURE 4 | Apoptosis related gene expression ratio in treated (50 $\mu \mathrm{g} / \mathrm{mL}$ E. lactis secretion metabolites) and untreated control HeLa cells for $24 \mathrm{~h}$.

probiotic Propionibacterium freudenreichii could kill HT-29 colorectal adenocarcinoma cells through apoptosis in vitro via its metabolites (the short chain fatty acids, acetate and propionate; Lan et al., 2007). Furthermore, the investigation results of the effect of probiotic Bacillus polyfermenticus on the growth of human colon cancer cells including HT-29, 
DLD-1, and Caco-2 cells have illustrated that B. polyfermenticus can inhibit tumor growth and its anticancer activity occurs through suppressing ErbB2 and ErbB3 genes (Ma et al., 2010). Based on our findings, the induction of apoptosis by E. lactis IW5 is related to extrinsic IL-3 receptor pathway and it is deferent from Taxol's apoptosis induction (intrinsic mitochondria apoptosis pathway).

\section{REFERENCES}

Adlerberth, I., Ahrne, S., Johansson, M. L., Molin, G., Hanson, L. A., and Wold, A. E. (1996). A mannose-specific adherence mechanism in Lactobacillus plantarum conferring binding to the human colonic cell line HT-29. Appl. Environ. Microbiol. 62, 2244-2251.

Baldwin, C., Millette, M., Oth, D., Ruiz, M. T., Luquet, F. M., and Lacroix, M. (2010). Probiotic Lactobacillus acidophilus and L. casei mix sensitize colorectal tumoral cells to 5-fuorouracil-induced apoptosis. Nutr. Cancer 62, 371-378. doi: 10.1080/01635580903407197

Bhardwaj, A., Gupta, H., Kapila, S., Kaur, G., Vij, S., and Malik, R. K. (2010). Safety assessment and evaluation of probiotic potential of bacteriocinogenic Enterococcus faecium KH 24 strain under in vitro and in vivo conditions. Int. J. Food Microbiol. 141, 156-164. doi: 10.1016/j.ijfoodmicro.2010.05.001

Chen, P., Zhang, Q., Dang, H., Liu, X., Tian, F., Zhao, J., et al. (2014). Screening for potential new probiotic based on probiotic properties and $\alpha$-glucosidase inhibitory activity. Food Conrol 35, 65-72. doi: 10.1016/j.foodcont.2013.06.027

Collins, J. K., Thornton, G., and Sullivan, G. O. (1998). Selection of probiotic strains for human applications. Int. Dairy J. 8, 487-490. doi: 10.1016/S09586946(98)00073-9

Conway, P. L., and Kjelleberg, S. (1989). Protein-mediated adhesion of Lactobacillus fermentum strain 737 to mouse stomach squamous epithelium. J. Gen. Microbiol. 135, 1175-1186.

Dabek, M., Mccrae, S. I., Stevens, V. J., Duncan, S. H., and Louis, P. (2008). Distribution of beta-glucosidase and beta-glucuronidase activity and of betaglucuronidase gene gus in human colonic bacteria. FEMS Microbiol. Ecol. 66, 487-495. doi: 10.1111/j.1574-6941.2008.00520.x

Delgado, S., O'sullivan, E., Fitzgerald, G., and Mayo, B. (2007). Subtractive screening for probiotic properties of Lactobacillus species from the human gastrointestinal tract in the search for new probiotics. J. Food Sci. 72, M310M315. doi: 10.1111/j.1750-3841.2007.00479.x

Dimitonova, S. P., Danova, S. T., Serkedjieva, J. P., and Bakalov, B. V. (2007). Antimicrobial activity and protective properties of vaginal lactobacilli from healthy Bulgarian women. Anaerobe 13, 178-184. doi: 10.1016/j.anaerobe.2007.08.003

Donaldson, M. S. (2004). Nutrition and cancer: a review of the evidence for an anti-cancer diet. Nutr. J. 3:19. doi: 10.1186/1475-2891-3-19

FAO/WHO (2001). Food and Agriculture Organization of the United Nations, World Health Organization. Report of a Joint FAO-WHO Expert Consultation on Evaluation of Health and Nutritional Properties of Probiotics in Food Including Powder Milk with Live Lactic Acid Bacteria. Córdoba, 2001. Available at: http://www.who.int/foddsafety/publications/fs_manage-ment/probiotics.pdf

Fisher, K., and Phillips, C. (2009). The ecology, epidemiology and virulence of Enterococcus. Microbiology 155, 1749-1757. doi: 10.1099/mic.0.026385-0

Forsyth, C. B., Farhadi, A., Jakate, S. M., Tang, Y., Shaikh, M., and Keshavarzian, A. (2009). Lactobacillus GG treatment ameliorates alcohol-induced intestinal oxidative stress, gut leakiness, and liver injury in a rat model of alcoholic steatohepatitis. Alcohol 43, 163-172. doi: 10.1016/j.alcohol.2008.12.009

Franz, C. M., Stiles, M. E., Schleifer, K. H., and Holzapfel, W. H. (2003). Enterococci in foods-a conundrum for food safety. Int. J. Food Microbiol. 88, 105-122. doi: 10.1016/S0168-1605(03)00174-0

Galvez, A. A., Dubois-Dauphin, R., Ghalfi, H., Campos, D., and Thonart, P. (2009). Description of two Enterococcus strains isolated from traditional Peruvian artisanal-produced cheeses with a bacteriocin-like inhibitory activity. Biotechnol. Agron. Soc. 13, 349-356.

Granato, D., Perotti, F., Masserey, I., Rouvet, M., Golliard, M., Servin, A., et al. (1999). Cell surface-associated lipoteichoic acid acts as an adhesion factor for

\section{ACKNOWLEDGMENTS}

The financial support of the University Putra Malaysia (Putra Grant research no. 9443200), Tabriz University of Medical Sciences, and the moral patronage of Abolfazl Barzegari and Simin Sharifi are gratefully acknowledged.

attachment of Lactobacillus johnsonii La1 to human enterocyte-like Caco-2 cells. Appl. Environ. Microbiol. 65, 1071-1077.

Haghshenas, B., Abdullah, N., Nami, Y., Radiah, D., Rosli, R., and Khosroushahi, A. Y. (2014a). Different effects of two newly-isolated probiotic Lactobacillus plantarum $15 \mathrm{HN}$ and Lactococcus lactis subsp. lactis $44 \mathrm{Lac}$ strains from traditional dairy products on cancer cell lines. Anaerobe 30, 51-59. doi: 10.1016/j.anaerobe.2014.08.009

Haghshenas, B., Nami, Y., Abdullah, N., Radiah, D., Rosli, R., and Khosroushahi, A. Y. (2014b). Anti-proliferative effects of Enterococcus strains isolated from fermented dairy products on different cancer cell lines. J. Funct. Foods 11, 363-374. doi: 10.1016/j.jff.2014.10.002

Haghshenas, B., Nami, Y., Abdullah, N., Radiah, D., Rosli, R., Barzegari, A., et al. (2015a). Potentially probiotic acetic acid bacteria isolation and identification from traditional dairies microbiota. Int. J. Food Sci. Technol. 50, 1056-1064. doi: $10.1111 /$ ijfs. 12718

Haghshenas, B., Nami, Y., Abdullah, N., Radiah, D., Rosli, R., and Khosroushahi, A. Y. (2015b). Anticancer impacts of potentially probiotic acetic acid bacteria isolated from traditional dairy microbiota. LWT-Food Sci. Technol. 60, 690-697. doi: 10.1016/j.lwt.2014.09.058

Howarth, G. S., and Wang, H. (2013). Role of endogenous microbiota, probiotics and their biological products in human health. Nutrients 5, 58-81. doi: 10.3390/nu5010058

Hu, P., Song, W., Shan, Y., Du, M., Huang, M., Song, C., et al. (2015). Lactobacillus paracasei subsp. paracasei M5L induces cell cycle arrest and calreticulin translocation via the generation of reactive oxygen species in HT-29 cell apoptosis. Food Funct. 6, 2257-2265. doi: 10.1039/c5fo00248f

Iyer, C., Kosters, A., Sethi, G., Kunnumakkara, A. B., Aggarwal, B. B., and Versalovic, J. (2008). Probiotic Lactobacillus reuteri promotes TNFinduced apoptosis in human myeloid leukemia-derived cells by modulation of NF-kappaB and MAPK signalling. Cell. Microbiol. 10, 1442-1452. doi: 10.1111/j.1462-5822.2008.01137.x

Kim, Y., Oh, S., Yun, H. S., Oh, S., and Kim, S. H. (2010). Cell-bound exopolysaccharide from probiotic bacteria induces autophagic cell death of tumour cells. Lett. Appl. Microbiol. 51, 123-130. doi: 10.1111/j.1472765X.2010.02859.x

Lan, A., Lagadic-Gossmann, D., Lemaire, C., Brenner, C., and Jan, G. (2007). Acidic extracellular $\mathrm{pH}$ shifts colorectal cancer cell death from apoptosis to necrosis upon exposure to propionate and acetate, major end-products of the human probiotic propionibacteria. Apoptosis 12, 573-591. doi: 10.1007/s10495-0060010-3

Lee, N. K., Kim, S. Y., Han, K. J., Eom, S. J., and Paik, H. D. (2014). Probiotic potential of Lactobacillus strains with anti-allergic effects from kimchi for yogurt starters. LWT-Food Sci. Technol. 58, 130-134. doi: 10.1016/j.lwt.2014.02.028

Lin, P. W., Nasr, T. R., Berardinelli, A. J., Kumar, A., and Neish, A. S. (2008). The probiotic Lactobacillus GG may augment intestinal host defense by regulating apoptosis and promoting cytoprotective responses in the developing murine gut. Pediatr. Res. 64, 511-516. doi: 10.1203/PDR.0b013e3181 $827 \mathrm{cof}$

Ma, E. L., Choi, Y. J., Choi, J., Pothoulakis, C., Rhee, S. H., and Im, E. (2010). The anticancer effect of probiotic Bacillus polyfermenticus on human colon cancer cells is mediated through ErbB2 and ErbB3 inhibition. Int. J. Cancer 127, 780-790. doi: 10.1002/ijc.25011

Maldonado, N. C., De Ruiz, C. S., Otero, M. C., Sesma, F., and NaderMacias, M. E. (2012). Lactic acid bacteria isolated from young calves: characterization and potential as probiotics. Res. Vet. Sci. 92, 342-349. doi: 10.1016/j.rvsc.2011.03.017 
Mehra, N., Majumdar, R. S., Kumar, S., and Dhewa, T. (2012). Probiotics: preventive and clinical applications. Biotechnol. Res. Bull. 1, 15-20.

Merghoub, N., Benbacer, L., Amzazi, S., Morjani, H., and El Mzibri, M. (2009). Cytotoxic effect of some Moroccan medicinal plant extracts on human cervical cell lines. J. Med. Plants Res. 3, 1045-1050.

Mosmann, T. (1983). Rapid colorimetric assay for cellular growth and survival: application to proliferation and cytotoxicity assays. J. Immunol. Methods 65, 55-63. doi: 10.1016/0022-1759(83)90303-4

Nami, Y., Abdullah, N., Haghshenas, B., Radiah, D., Rosli, R., and Khosroushahi, A. Y. (2014a). Probiotic assessment of Enterococcus durans 6HL and Lactococcus lactis $2 \mathrm{HL}$ isolated from vaginal microflora. J. Med. Microbiol. 63, 1044-1051. doi: 10.1099/jmm.0.074161-0

Nami, Y., Abdullah, N., Haghshenas, B., Radiah, D., Rosli, R., and Khosroushahi, A. Y. (2014b). Assessment of probiotic potential and anticancer activity of newly isolated vaginal bacterium Lactobacillus plantarum 5BL. Microbiol. Immunol. 58, 492-502. doi: 10.1111/1348-0421.12175

Nami, Y., Abdullah, N., Haghshenas, B., Radiah, D., Rosli, R., and Khosroushahi, A. Y. (2014c). Probiotic potential and biotherapeutic effects of newly isolated vaginal Lactobacillus acidophilus 36YL strain on cancer cells. Anaerobe 28, 29-36. doi: 10.1016/j.anaerobe.2014.04.012

Nami, Y., Abdullah, N., Haghshenas, B., Radiah, D., Rosli, R., and Yari Khosroushahi, A. (2014d). A newly isolated probiotic Enterococcus faecalis strain from vagina microbiota enhances apoptosis of human cancer cells. J. Appl. Microbiol. 117, 498-508. doi: 10.1111/jam.12531

Nowroozi, J., Mirzaii, M., and Norouzi, M. (2004). Study of Lactobacillus as probiotic bacteria. Iranian J. Public Health 33, 1-7.

Ouwehand, A. C. (2007). Antiallergic effects of probiotics. J. Nutr. 137, 794S-797S.

Ouwehand, A. C., Salminen, S., and Isolauri, E. (2002). Probiotics: an overview of beneficial effects. Antonie Van Leeuwenhoek 82, 279-289. doi: 10.1023/A:1020620607611

Paolillo, R., Romano Carratelli, C., Sorrentino, S., Mazzola, N., and Rizzo, A. (2009). Immunomodulatory effects of Lactobacillus plantarum on human colon cancer cells. Int. Immunopharmacol. 9, 1265-1271. doi: 10.1016/j.intimp.2009.07.008
Prisciandaro, L. D., Geier, M. S., Butler, R. N., Cummins, A. G., and Howarth, G. S. (2011). Evidence supporting the use of probiotics for the prevention and treatment of chemotherapy-induced intestinal mucositis. Crit. Rev. Food Sci. 51, 239-247. doi: 10.1080/10408390903551747

Rahmati, M. (2011). The apoptotic and cytotoxic effects of Polygonum avicular extract on Hela-S cervical cancer cell line. Afr. J. Biochem. Res. 5, 373-378.

Sarem, F., Sarem-Damerdji, L. O., and Nicolas, J. P. (1996). Comparison of the adherence of three Lactobacillus strains to Caco-2 and Int-407 human intestinal cell lines. Lett. Appl. Microbiol. 22, 439-442. doi: 10.1111/j.1472765X.1996.tb01198.x

Sharma, S., Chaturvedi, J., Chaudhari, B. P., Singh, R. L., and Kakkar, P. (2012). Probiotic Enterococcus lactis IITRHR1 protects against acetaminopheninduced hepatotoxicity. Nutrition 28, 173-181. doi: 10.1016/j.nut.2011.0 2.012

Sharma, S., Singh, R. L., and Kakkar, P. (2011). Modulation of Bax/Bcl2 and caspases by probiotics during acetaminophen induced apoptosis in primary hepatocytes. Food Chem. Toxicol. 49, 770-779. doi: 10.1016/j.fct.2010.1 1.041

Shin, N. R., Moon, J. S., Shin, S. Y., Li, L., Lee, Y. B., Kim, T. J., et al. (2015). Isolation and characterization of human intestinal Enterococcus avium EFEL009 converting rutin to quercetin. Lett. Appl. Microbiol. doi: 10.1111/lam.12512 [Epub ahead of print]

Conflict of Interest Statement: The authors declare that the research was conducted in the absence of any commercial or financial relationships that could be construed as a potential conflict of interest.

Copyright (c) 2015 Nami, Haghshenas, Haghshenas, Abdullah and Yari Khosroushahi. This is an open-access article distributed under the terms of the Creative Commons Attribution License (CC BY). The use, distribution or reproduction in other forums is permitted, provided the original author(s) or licensor are credited and that the original publication in this journal is cited, in accordance with accepted academic practice. No use, distribution or reproduction is permitted which does not comply with these terms. 